\title{
Adhesion molecules in inflammatory bowel
}

\section{disease}

S C Jones, R E Banks, A Haidar, A J H Gearing, I K Hemingway, S H Ibbotson, M F Dixon, A T R Axon

\begin{abstract}
The ability of leucocytes to adhere to endothelium is essential for leucocyte migration into inflammatory sites. Some of these adhesion molecules are released from the cell surface and can be detected in serum. The soluble adhesion molecules intercellular adhesion molecule 1 (ICAM1), E selectin, and vascular cell adhesion molecule 1 (VCAM-1) were studied in the serum of patients with Crohn's disease, ulcerative colitis, and healthy controls. A second blood sample was taken from patients with active disease after one month of treatment and a third two months after remission was achieved. Tissue expression of the same adhesion molecules was studied by immunohistology. Circulating VCAM-1 concentrations were significantly higher in patients with active ulcerative colitis $(n=11$, median $=165 \mathrm{U} / \mathrm{ml}$ ) compared with patients with inactive ulcerative colitis $(n=10$, median $=117 \mathrm{U} / \mathrm{ml}, p<0.005)$, active Crohn's disease $(n=12$, median $=124 \mathrm{U} / \mathrm{ml}$, $p<0 \cdot 02)$, and controls $(n=90$, median $=50$ $\mathrm{U} / \mathrm{ml}, \mathbf{p}<0 \cdot 0001)$. Within each disease group there were no significant differences in $E$ selectin or ICAM-1
\end{abstract} concentrations between the active and inactive states, however, patients with active Crohn's disease had significantly higher ICAM-1 concentrations $(n=12$, median $=273 \mathrm{ng} / \mathrm{ml})$ than controls $(n=28$, median $=168, p<0.003)$. VCAM-1 concentrations fell significantly from pretreatment values to remission in active ulcerative colitis $(\mathbf{p}<\mathbf{0 \cdot 0 1})$. In Crohn's disease there was a significant fall in ICAM-1 both during treatment $(p<0 \cdot 01)$ and two months after remission $(p<0.02)$. Vascular expression of ICAM-1 occurred more often and was more intense in inflamed tissue sections from patients with ulcerative colitis and Crohn's disease than from controls. Vascular labelling with antibody to $E$ selectin also occurred more often in patients with active inflammatory bowel disease. In conclusion, increased circulating concentrations of selected adhesion molecules are associated with inflammatory bowel disease. There is also evidence of local upregulation, particularly of ICAM-1. Differential expression of adhesion molecules in tissue may play a part in the initiation of leucocyte migration and local inflammation; the function of circulating adhesion molecules is unknown, but may play a physiological part in blocking adhesion.

(Gut 1995; 36: 724-730)

Keywords: adhesion molecules, inflammatory bowel disease.

Inflammatory bowel disease is characterised by the infiltration of inflammatory cells derived from the circulation including monocytes, lymphocytes, and neutrophils. Several factors contribute to the local recruitment of inflammatory cells. These include the release of cytokines in the microenvironment and the interaction between adhesion molecules expressed on circulating inflammatory cells and those on their local target cells. The potential importance of these molecules in inflammatory conditions of the gastrointestinal tract is suggested by a recent paper ${ }^{1}$ in which an inhibitor of expression of $\beta_{2}$ integrins involved in leukocyte adhesion (NPC 15669) attenuated acetic acid induced colitis in rats.

Intercellular adhesion molecule 1 (ICAM-1) and vascular cell adhesion molecule 1 (VCAM1) are cytokine inducible glycoproteins belonging to the immunoglobulin supergene family. ${ }^{2}$ ICAM-1 is constitutively expressed on a limited number of cell types including endothelial cells (weakly) ${ }^{3}$ but is induced on a wide variety of cells by inflammatory cytokines such as interleukin 1 (IL1), tumour necrosis factor (TNF), and interferon $\gamma$ (IFN $\gamma) .{ }^{45}$ Susceptible tissues include haemopoetic cells, epithelial cells, and endothelial cells. ICAM-1 is a ligand for the leucocyte integrins leukocyte function associated molecule-1 (LFA-1) and Mac- $1^{3}$ and participates in leucocyte adhesion to activated endothelial cells, $\mathrm{T}$ cell/antigen presenting cell, $\mathrm{T}$ cell $/ \mathrm{T}$ cell, and $\mathrm{T}$ cell/B cell interactions.

VCAM-1 is less widely distributed than ICAM-1 and is expressed by germinal centre dendritic cells, interdigitating dendritic cells, Kupffer cells, synovial lining cells, and renal proximal tubule cells. ${ }^{6-9}$ Endothelial cells also express VCAM-1 after activation by cytokines such as TNF $\alpha$, IL $1 \beta$, and IFN $\gamma$. It is primarily involved in lymphocyte and monocyte-endothelial cell interactions and binds to an integrin of the VLA4 class expressed on all leucocytes except neutrophils. T cell activation leads to kinase induced conformational changes of VLA-4, increasing the avidity of the binding with VCAM. ${ }^{10}$

$\mathrm{E}$ selectin is transiently expressed on endothelial cells only, after induction by IL1, TNF or lipopolysaccharide. ${ }^{11}$ IFN $\gamma$ seems to 
stabilise E selectin surface expression without prolonging the period of synthesis. ${ }^{12}$ It primarily mediates the neutrophil-endothelial cell interactions that modulate recruitment of neutrophils to sites of inflammation, ${ }^{13}$ but more recent studies have shown that it also mediates the adhesion of a subpopulation of resting $\mathrm{CD} 4+$ memory cells to activated endothelium. ${ }^{14}$

Increased expression of adhesion molecules has been described in a variety of inflammatory disorders such as dermatoses, ${ }^{15}$ asthma, ${ }^{16}$ and arthritis. ${ }^{17}$ Soluble variants of some adhesion molecules such as circulating $\mathrm{E}$ selectin, ICAM-1, and VCAM-1 ${ }^{18}{ }^{19}$ have been found in normal serum and at increased concentrations in several disorders including malignant diseases, ${ }^{2021} \mathrm{HIV}$ infection, ${ }^{22}$ psoriasis, ${ }^{23}$ and uveitis. $^{24}$

In addition, Leeuwenberg et al, ${ }^{25}$ found that the amount of soluble adhesion molecules released from human umbilical vein endothelial cells stimulated with TNF, IL 1, or lipopolysaccharide, correlated directly with cell surface expression. At the present time, the significance and mechanism of release of these molecules is unknown.

The aims of this study were twofold: firstly, to investigate concentrations of circulating forms of the adhesion molecules $\mathrm{E}$ selectin, VCAM-1, and ICAM-1 in inflammatory bowel disease, and their correlation with clinical and immunological parameters of disease activity and von Willebrand factor. Von Willebrand factor is important in the adhesion of platelets to endothelial cells ${ }^{26}$ and its release is thought to reflect vascular injury. ${ }^{27}$ The second aim was to study the local expression of these three adhesion molecules in patients with ulcerative colitis, Crohn's disease, and controls.

\section{Methods}

\section{Patients}

Blood samples were collected from 43 patients with inflammatory bowel disease defined according to standard clinical, histological, and radiological methods. Twenty two patients had Crohn's disease (age range 19-68) (12 active: defined as Crohn's disease activity index $\left.(\mathrm{CDAI})>150^{28}\right)$, and 21 had ulcerative colitis (age range 18-80) (11 active: defined as mild (two patients), moderate (nine patients), or severe according to Truelove and Witt's criteria $^{29}$ ). A second blood sample was taken from patients with active disease after one month of treatment and a third, two months after remission was achieved. Samples were allowed to clot, the serum removed within 30 minutes of venepuncture, and stored at $-70^{\circ} \mathrm{C}$ until analysis.

Active disease - 13 patients were treated with $30 \mathrm{mg}$ prednisolone daily, three patients who relapsed while receiving corticosteroids were given azathioprine, another patient opted for treatment with a polymeric diet (Triosorbon, E Merck, Alton, Hampshire, UK), the other three had distal ulcerative colitis and received either 5-ASA or corticosteroid enemas, but one of these failed to respond and required oral prednisolone. Two patients with Crohn's disease and one with ulcerative colitis who relapsed while taking prednisolone were referred for surgery. Seven patients with active ulcerative colitis were taking aminosalicylates (maintenance dose) and these were continued in the same dose throughout the study.

Inactive disease - of the patients with inactive Crohn's disease, two were taking prednisolone (5 $\mathrm{mg}$ and $10 \mathrm{mg}$ ) and azathioprine, two azathioprine alone, two prednisolone alone $(2.5$ and $10 \mathrm{mg}$ ), and four were receiving no treatment. Three patients included in the inactive ulcerative colitis group were taking prednisolone $(5,7 \cdot 5$, and $10 \mathrm{mg})$ and aminosalicylates, three were taking aminosalicylates alone, and four patients were not taking any drugs.

Samples were also obtained from 90 healthy laboratory and clinical personnel and blood donors (age range 18-60) and assayed for E selectin and VCAM-1. In the case of ICAM1 , a subgroup of 27 of the control samples (age range 24-54) were assayed.

Endoscopic biopsy specimens or surgical sections of small or large bowel, or both, were taken from eight patients with Crohn's disease and nine patients with ulcerative colitis. These included biopsy specimens from six patients with active ulcerative colitis and two patients with active Crohn's disease who also had serum samples taken. Endoscopic biopsy specimens from eight patients undergoing colonoscopy for investigation of abdominal pain (in whom no abnormality was subsequently found) or sections from surgical specimens of patients with colonic carcinoma (obtained well away from the tumour area) and diverticular disease were used as normal controls.

\section{Assay of soluble adhesion molecules}

Concentrations of circulating ICAM-1 were measured with a commercial enzyme linked immunosorbent assay (ELISA) kit (British Biotechnology Products, Oxford, UK). Concentrations of circulating $\mathrm{E}$ selectin and VCAM-1 were measured using dual monoclonal antibody two site ELISAs as previously described. ${ }^{18} 2030$ The assays were standardised using a recombinant soluble form of $E$ selectin or VCAM-1 lacking their transmembrane and cytoplasmic domains and given an arbitary unitage against which all samples were measured. Inter and intra-assay coefficient of variation for all three ELISAs were $<10 \%$ and $<6 \%$ respectively over a range of values.

\section{Von Willebrand factor assay}

Assay of von Willebrand factor antigen was performed by ELISA using rabbit antihuman von Willebrand factor polyclonal antibodies (Dako Ltd, UK) according to the method described by Short et al. ${ }^{31}$ Intra-assay and interassay coefficients of variation were $3 \cdot 1 \%$ and $3.6 \%$ respectively.

The following were also measured for each patient: haemoglobin, white cell and platelet 

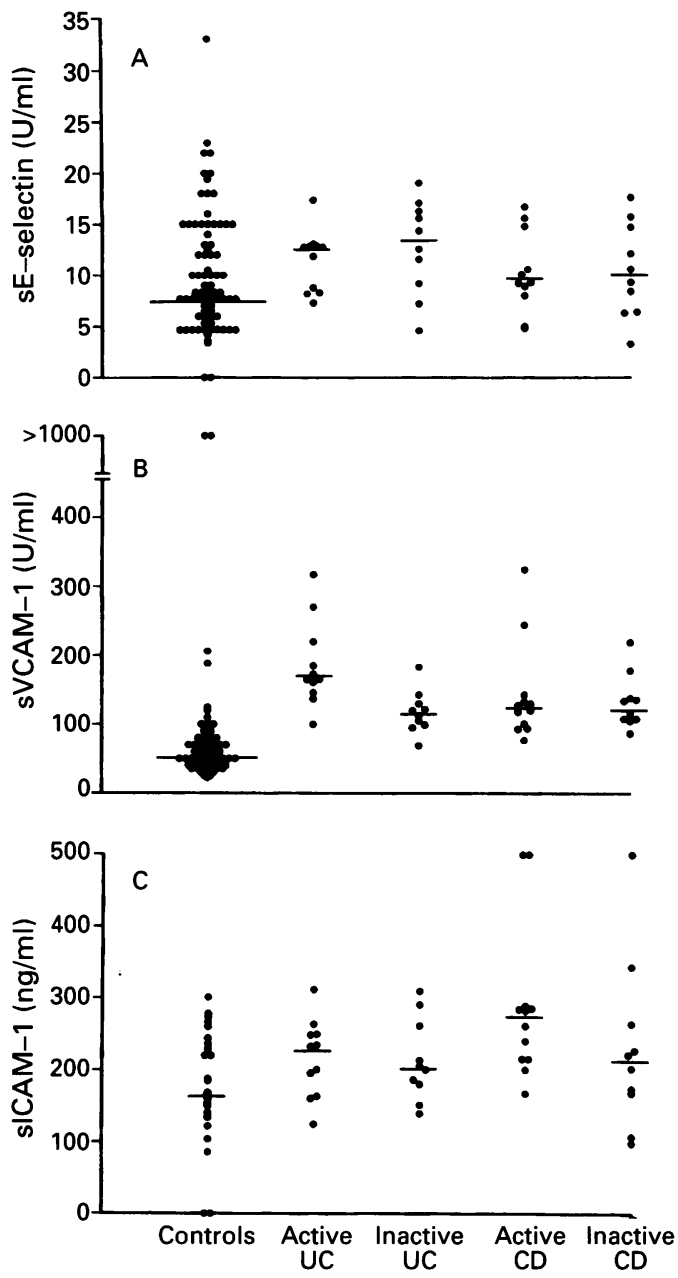

Figure 1: Serum concentrations of soluble forms of the adhesion molecules: (A) E selectin, (B) VCAM-1, and (C) ICAM-1 in patients with active and inactive inflammatory bowel disease and in controls. The horizontal lines represent median values.

count (automated Coulter Counter, Coulter Electronics, Luton, Bedfordshire, UK); plasma viscosity (Coulter Viscometer, Counter Electronics); erythrocyte sedimentation rate (ESR) (Westergen method); serum $\mathrm{C}$ reactive protein (Behring Nephelometer, Hoechst UK, Hounslow, UK) and serum albumin (sequential multiple auto-analyser with computer; Technicon, Basingstoke, Hampshire, UK).

\section{Immunohistochemistry}

Paraffin wax embedded sections were dewaxed in xylene and rehydrated. Endogenous peroxidase activity was blocked by incubating sections in $0.3 \%$ hydrogen peroxide in methanol for 10 minutes at room temperature followed by incubating with $0 \cdot 1 \%$ trypsin at $37^{\circ} \mathrm{C}$ for 20 minutes. After incubating in normal mouse serum ( 1 in 5), goat polyclonal antibodies to E selectin, VCAM-1, or ICAM-1 (from Dr A Gearing) diluted 1 in 200 or control (normal goat serum) were then applied and left overnight at room temperature. After washing, biotinylated monoclonal antigoat antibody (B3148, Sigma Chemicals), diluted 1 in 250 was applied and sections incubated for 30 minutes at room temperature. After a further washing step, colour was developed using an avidin-biotin-peroxidase complex (Dako
ABC-HRP complex kit) according to the manufacturer's instructions followed by washing and incubation in DAB (diaminobenzidine).

\section{Histological assessment of biopsy specimens and} surgical sections

All sections were assessed by a single observer (blinded to the antibody applied to the section), for the degree of positivity in all vessels and other tissue types by the antibodies.

\section{Statistics}

Methods appropriate to non-parametric data were used throughout: the Mann-Whitney $U$ test to assess differences between the different patient groups, Wilcoxon matched pairs signed rank sum test to determine differences in the same patient group after treatment, and Spearman's rank coefficient to assess correlation. The analyses were performed by computer using the statistical analysis program CSS.

\section{Results}

Circulating adhesion molecules (Fig $1 A-C$ )

VCAM-1 concentrations were significantly higher in patients with active ulcerative colitis (median $=165 \mathrm{U} / \mathrm{ml}$ ) compared with patients with inactive ulcerative colitis (median $=117$, $\mathrm{p}<0.005)$ active Crohn's disease (median $=124, \mathrm{p}<0.02)$, and controls $(\mathrm{n}=90$, median $=50, p<0 \cdot 0001)$. VCAM-1 concentrations were also significantly greater in patients with both active and inactive Crohn's disease than controls $(p=0.0001)$. There were no significant differences in E selectin or ICAM-1 concentrations between patients with active and inactive disease, although patients with active Crohn's disease had significantly higher ICAM-1 concentrations (median $=273 \mathrm{ng} / \mathrm{ml}$ ) than controls $(n=28$, median $=168, p<0.003)$. VCAM-1 concentrations fell significantly from pretreatment values to remission in active ulcerative colitis (pretreatment median $=165$, post-treatment median $=138, \mathrm{p}<0.01)$. In Crohn's disease concentrations of soluble adhesion molecules were available after treatment in 11 of 12 patients with active disease. There was a significant fall in ICAM-1 both during treatment $(p<0.01)$ and two months after remission (pretreatment median $=262$, post-treatment $=205, \mathrm{p}<0.02)($ Fig 2).

There was no significant difference in sICAM-1 concentrations between the patients with inactive disease who were taking corticosteroids compared with those who were not. The two highest values of SICAM-1 (500 and 344) occurred in patients with inactive Crohn's disease who were taking 10 and $5 \mathrm{mg}$ prednisolone respectively.

In patients with ulcerative colitis, sVCAM-1 correlated with von Willebrand factor $(r=0.67$, $\mathrm{p}<0.003)$, platelet count $(r=0.43, \mathrm{p}=0.05)$, ESR $(r=0.62, \quad \mathrm{p}<0.01)$, and inversely with haemoglobin $(r=-0.65, \mathrm{p}<0.004)$ and albumin $\quad(r=-0.65, \quad \mathrm{p}<0.006)$. SICAM-1 
A

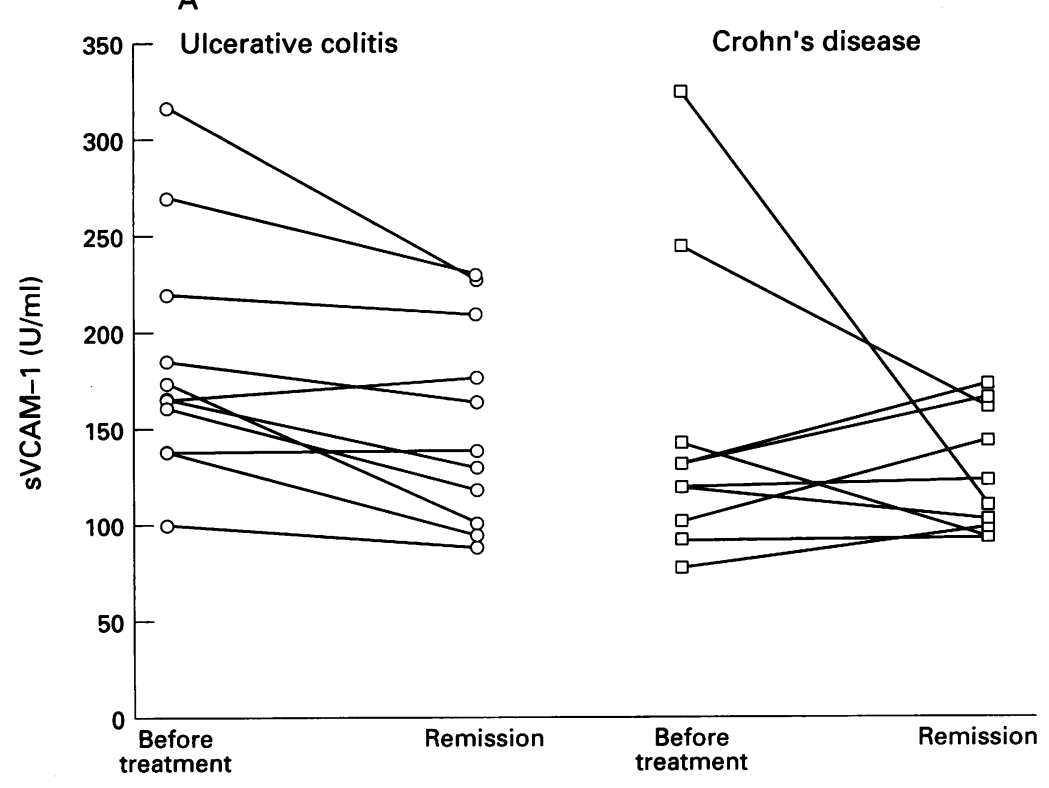

$\mathrm{p}<0.03)$, and inversely with haemoglobin $(r=-0.47, \mathrm{p}<0.04)$ and albumin $(r=-0.63$, $\mathrm{p}<0.007)$. In patients with Crohn's disease there was an inverse correlation between von Willebrand factor and albumin in patients with active disease only $(r=-0.686, p=0.02)$.

$\mathrm{E}$ selectin concentrations did not correlate with any parameters.

Local expression of adhesion molecules

The Table summarises the results of endothelial labelling.

Controls $(\mathrm{n}=8)$ - blood vessels were all negative for $\mathrm{E}$ selectin apart from one case, which had minimal labelling. Seven cases were positive VCAM-1 and five for ICAM-1. Figure 3A shows a control section labelled with ICAM-1 antibody (regarded as being negative). The occasional pigmented macrophage seen in this section represents pseudomelanosis coli.

Ulcerative colitis (nine involved and one uninvolved) - in four of the inflamed specimens there was endothelial positivity for E selectin. In one of these cases a section was also available taken proximal to the inflamed area, which was negative. Nine of 10 sections contained vessels positive for VCAM-1, although staining did not seem to be any more extensive than seen in controls. The most striking finding in this group was that all patients had vessels that were positive for ICAM-1, most of them strongly so. Figure 3B illustrates a section showing appreciable endothelial positivity for ICAM-1. More patients with ulcerative colitis tended to express $\mathrm{E}$ selectin than controls.

Crohn's disease - there were nine involved cases (six colonic, three ileum) and three uninvolved (one caecum, two ileum). Of the involved cases, four contained vessels positive for $\mathrm{E}$ selectin (one case of patchy involvement was positive only in the inflamed areas), all cases were positive for VCAM-1, six moderately so. All cases had positive vascular labelling for ICAM-1, which was intense in three sections. The three cases of uninvolved bowel were moderately positive for both VCAM-1 and ICAM-1, but not E selectin.

Other tissue components - occasional inflammatory cells in the lamina propria were positive for ICAM-1 expression with a slight increase in the number of positive cells in ulcerative colitis and Crohn's disease compared with controls.

Endothelial labelling results

\begin{tabular}{|c|c|c|c|}
\hline & \multicolumn{3}{|c|}{$\begin{array}{l}\text { Number of cases with vascular endothelium } \\
\text { positive for adhesion molecule }\end{array}$} \\
\hline & Controls & $\begin{array}{l}\text { Ulcerative colitis } \\
\text { (involved) }\end{array}$ & $\begin{array}{l}\text { Crohn's disease } \\
\text { (involved) }\end{array}$ \\
\hline $\begin{array}{l}\text { E selectin } \\
\text { VCAM-1 } \\
\text { ICAM-1 }\end{array}$ & $\begin{array}{l}1 \text { of } 8 \\
7 \text { of } 8 \\
5 \text { of } 8\end{array}$ & $\begin{array}{l}4 \text { of } 9 \\
8 \text { of } 9 \\
9 \text { of } 9 \text { (6 intense) }\end{array}$ & $\begin{array}{l}4 \text { of } 9 \\
9 \text { of } 9 \\
9 \text { of } 9 \text { (3 intense) }\end{array}$ \\
\hline
\end{tabular}

Local expression of the adhesion molecules $E$ selectin, VCAM-1, and ICAM-1 in sections taken from inflamed areas of small or large bowel in patients with Crohn's disease and ulcerative colitis and in 'controls'. Control tissue was taken from patients undergoing resection for carcinoma or diverticular disease, well away from the affected area or from patients who had normal colonoscopic and histological findings. and inactive Crohn's disease (medians $=0.99$ range $0.55-2.76$ and 1.04 , range $0.41-1.92$ respectively). In patients with ulcerative colitis von Willebrand factor correlated with platelet count $(r=0.52, \quad \mathrm{p}<0.02), \quad \mathrm{ESR} \quad(r=0.79$, $\mathrm{p}<0.0008)$, C reactive protein $(r=0.49$, 

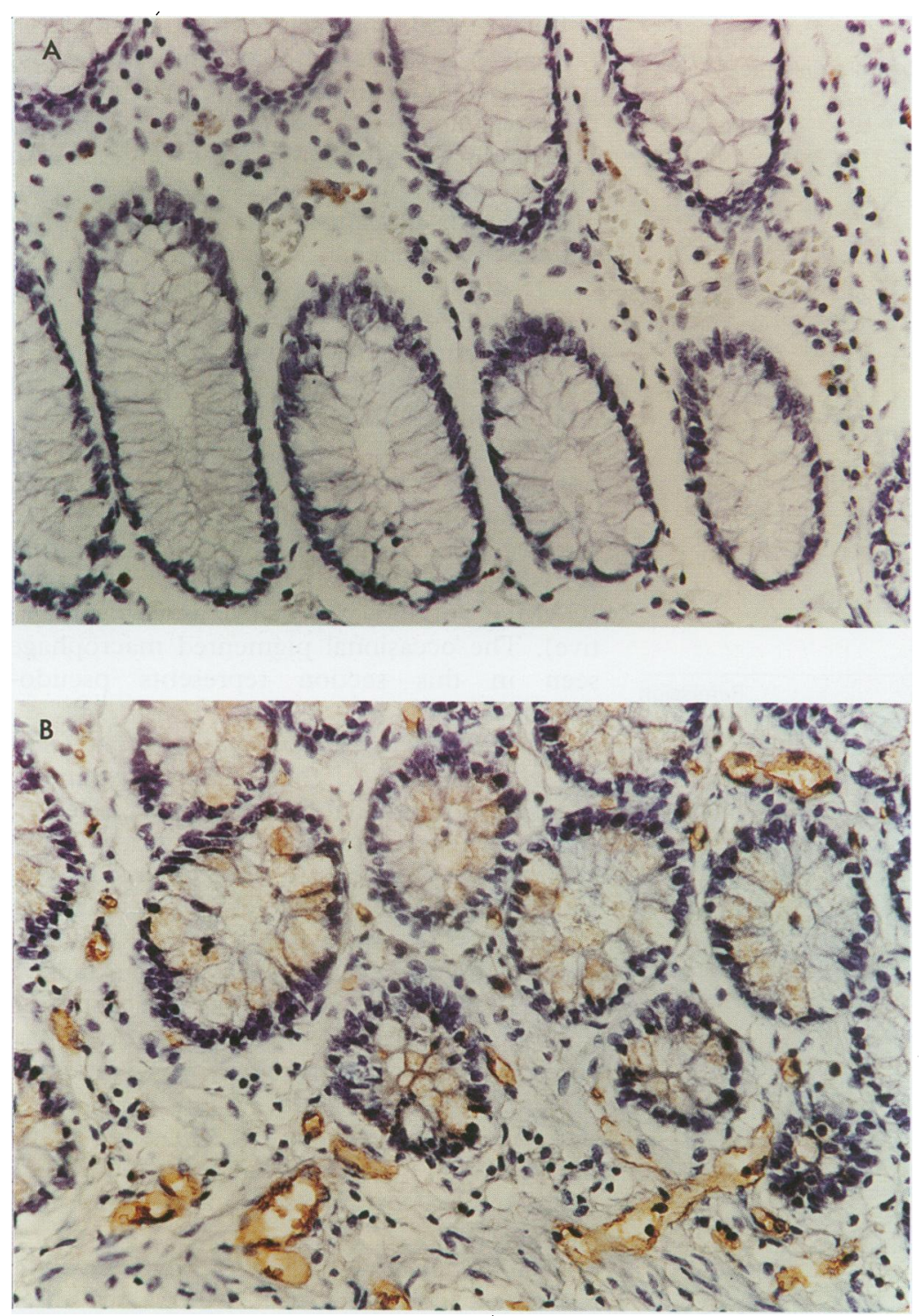

Figure 3: Sections taken from $(A)$ : control patient (negative for vascular adhesion molecule expression) and (B): patient with active ulcerative colitis showing intense labelling with ICAM-1 antibody. The occasional pigmented macrophage seen in the section taken from the control patient represents pseudomelanosis coli.

No cells in the lamina propria (other than endothelial cells) showed specific labelling for E selectin or VCAM-1. There was epithelial connective tissue labelling in a few cases. In these cases there was diffuse epithelial labelling present in an identical pattern with all three antibodies, which was considered to be nonspecific. In one case of active Crohn's disease, there was a distinct pattern of focal epithelial labelling with the ICAM antibody only, which may therefore be specific.

There was no obvious relation between the tissue concentrations of adhesion molecules and their circulating concentrations in the eight patients who had both measured.

\section{Discussion}

This study has shown that the concentration of selected circulating adhesion molecules and the expression of endothelial cell surface adhesion molecules are increased in inflammatory bowel disease. There was a dissociation between circulating and local expression. VCAM-1 concentrations were significantly increased in the circulation of patients with active ulcerative colitis without prominent local upregulation compared with controls. This may reflect differences in turnover rates. There was also no obvious relation between the tissue concentrations of adhesion molecules and their circulating concentrations in the eight patients who had both measured.

Previous studies in inflammatory bowel disease have shown that vascular endothelium and lamina propria mononuclear phagocytes express ICAM-1..$^{32-34}$ Our results are in agreement with this, but we did not see such extensive lamina propria mononuclear cell staining. VCAM-1 is constitutively expressed in lymphoid aggregates in normal colonic mucosa but is not significantly enhanced in inflammation, conversely, E selectin was not detected in normal mucosa but was present on endothelial surfaces in association with active inflammation. ${ }^{34-36}$ Several epithelial cell types including human colonic adenocarcinoma cell lines and colonic cancer cells in vivo express ICAM-1. ${ }^{37} 38$ In a few of our cases there was epithelial labelling that seemed to be nonspecific, in that it was diffusely present with all three antibodies. In one case, however, the epithelial labelling did seem to be specific in that there was a distinct pattern of reactivity only seen with the ICAM antibody and not with other antibodies of the same species.

The differential local expression of adhesion molecules that we found may reflect differences in local cytokine concentrations. The expression of E selectin, VCAM-1, and ICAM-1 on endothelial cells is induced by IL1 and TNF ${ }^{39}{ }^{40}$; both of which are produced in increased amounts in the inflammatory bowel disease. ${ }^{41-43}$ The mechanism by which soluble adhesion molecules are released remains unclear. The differential serum concentrations that we saw may be caused by differences in the rate of shedding of the molecule from vascular endothelial cells induced by differences in cytokine profile or concentration.

The concentration of soluble ICAM-1 in patients with active Crohn's disease and VCAM-1 in patients with ulcerative colitis fell after corticosteroid treatment. Corticosteroids are known to affect ICAM-1 expression. ${ }^{44}$ Although, as stated previously, in the inactive disease group there was no significant difference between patients taking corticosteroids and those who were not. However, patients were receiving lower doses of corticosteroids than the active group. The reduction may result from down regulation of the release or expression of adhesion molecules, or both. By down regulating the expression of these molecules on endothelium, their interaction with immune cells will be reduced and inflammatory activity diminished. This mechanism of action may be of importance in inducing remission in inflammatory bowel disease.

Von Willebrand is increased as part of the acute phase response in humans ${ }^{45}$ and is increased in inflammatory bowel disease. ${ }^{46}$ Stevens et al ${ }^{46}$ found, as we did, that serum von Willebrand activity was unrelated to disease activity in Crohn's disease but was 
significantly raised in active compared with inactive ulcerative colitis. They suggested that the increase is compatible with the proposal that vascular injury is an early event in the pathogenesis of Crohn's disease. ${ }^{47}$ If circulating concentrations of adhesion molecules are a reflection of vascular inflammation, the increased concentrations of SICAM-1 in a few patients with inactive Crohn's disease would be compatible with continuing vascular inflammation in patients with inactive Crohn's disease.

It is possible that the positive correlation between sICAM-1 and the acute phase protein $C$ reactive protein, and the negative correlation with the negative acute phase protein albumin reflects the activity of circulating cytokines. As previously discussed, cytokines such as IL1 and $T N F \alpha$, are important in upregulating expression of ICAM-1. These cytokines, together with IL6, can differentially regulate production of acute phase proteins. ${ }^{48}$

The reason why two of the healthy controls had VCAM concentrations of $>1000 \mathrm{U} / \mathrm{ml}$ is unclear but probably does not result from assay interference as normal values of ICAM-1 and $E$ selectin were detected in these samples using assays of a similar design. Similar concentrations of VCAM-1 were detected in repeat samples two months later.

The physiological importance of these soluble molecules is unclear; they may merely represent a spill over from the cell bound molecule, alternatively, they may regulate cell adhesion by competition as indeed, both sICAM-1 and sVCAM-1 can support leucocyte adhesion when immobilised to plastic. ${ }^{49}$ By binding to receptors on leucocytes, soluble adhesion molecules may prevent adherence of inflammatory cells to vascular endothelium and hence diminish inflammation. On the other hand, they may trigger a response in a ligand bearing cell.

In conclusion, raised circulating concentrations of selected adhesion molecules are associated with inflammatory bowel disease and are related to disease activity in ulcerative colitis. There is also evidence of local upregulation, particularly of ICAM-1. Differential expression of adhesion molecules in tissue may play a part in the initiation of leucocyte migration and local inflammation; it is possible that circulating forms play a protective part in inflammation by competing in cell to cell adhesion. Further studies are required to determine their role in the inflammatory process.

Some of these data have previously been published in abstract form (Gut 1993; 34 (suppl 1): S12).

1 Noronha-Blob L, Lowe VC, Mulhauser RO, Burch RM NPC 15669, an inhibitor of neutrophil recruitment is efficacious in acetic acid-induced colitis in rats. Gastroenterology 1993; 104: 1021-9.

2 Simmons D, Makgoba MW, Seed B. ICAM, an adhesion ligand of LFA-1, is homologous to the neural cell ligand of LFA-1, is homologous to the neural

3 Dustin ML, Rothlein R, Bhan AK, Dinarello CA, Springer TA. Induction by IL-1 and interferon gamma: tissue distriTA. Induction by $\mathrm{IL}-1$ and interferon gamma: tissue distribution, biochemistry and function of a natural adh

4 Dustin ML, Staunton DE, Springer TA. Supergene families meet in the immune system. Immunol Today 1988; 9: 213-5.

5 Springer TA, Dustin ML, Kishimoto TK, Marlin SD. The lymphocyte function-associated LFA-1, CD2 and LFA-3 molecules: cell adhesion receptors of the immune system. Annu Rev Immunol 1987; 5: 223-52.

6 Freedman AS, Munro JM, Rice GE, Bevilacqua MP, Morimoto C, McIntyre BW, et al. Adhesion of human B cells to germinal centres in vitro involves VLA-4 and INCAM-110. Science 1990; 249: 1030-3.

7 Koch AE, Burrows JC, Haines KG, Carlos TM, Harlan JM, Joseph S, et al. Immunolocalization of endothelial and leukocyte adhesion molecules in human rheumatoid and osteoarthritic synovial tissues. Lab Invest 1991; 64: 313.

8 Rice GE, Munro JM, Corless C, Bevilacqua MP. Vascular and nonvascular expression of INCAM-110: a target for mononuclear leukocyte adhesion in normal and inflamed human tissues. Am $\mathcal{F}$ Pathol 1991; 138: 385-93.

9 Seron D, Cameron JS, Haskard DO. Expression of VCAM-1 in the normal and diseased kidney. Nephrol Dial Transplant 1991; 6: 917-22.

10 Shimizu Y, van Seventer GA, Horgan KJ, Shaw S Regulated expression and binding of three VLA (beta 1 ) integrin receptors on T cells. Nature 1990; 345: 250-3.

11 Bevilacqua MP, Pober JS, Mendrick DL, Cotran RS, Gimbrone MA Jr. Identification of an inducible endothelial-leucocyte adhesion molecule. Proc Natl Acad Sci USA 1987; 84: 9238-42.

12 Doukas J, Pober JS. IFN-gamma enhances endothelial activation induced by tumour necrosis factor but not IL-1. f Immunol 1990; 145: 1727.

13 Bevilacqua MP, Stengelin S, Gimbrone MA Jr, Seed B. Endothelial leucocyte adhesion molecule 1: an inducible receptor for neutrophils related to complement regulatory proteins and lectins. Science 1989; 243: 1160-4.

14 Shimizu Y, Shaw S, Graber N, Gopal TV, Horgan KJ, Van Seventer GA, et al. Activation-independent binding of human memory $\mathrm{T}$ cells to adhesion molecule ELAM-1 Nature 1991; 349: 799-802.

15 Katz AM, Rosenthal D, Sauder DN. Cell adhesion molecules. Int $\mathcal{F}$ Dermatol 1991; 30: 153-60.

16 Wegner CD, Gundel RH, Reilly P, Haynes N, Letts LG, Rothlein R. Intercellular adhesion molecule-1 (ICAM-1) in the pathogenesis of asthma. Science 1990; 247: 456-9.

17 Hale LP, Martin ME, McCollum DE, Nunley JA, Springer $\mathrm{TA}$, Singer KH, et al. Immunohistologic analysis of the distribution of cell adhesion molecules within the inflammatory synovial microenvironment. Arthritis Rheum 1989; 32: $22-30$.

18 Gearing AJH, Hemingway IK, Pigott R, Hughes J, Rees AJ, Cashman SJ. Soluble forms of vascular adhesion molecules, E-selectin, ICAM-1 and VCAM-1: pathologica significance. Ann NY Acad Sci 1992; 667: 324-31.

19 Gearing AJH, Newman W. Circulating adhesion molecules in disease. Immunol Today 1993; 14: 506-12.

20 Banks RE, Gearing AJH, Hemingway IK, Norfolk DR, Perren TJ, Selby PJ. Circulating intercellular adhesion molecule-1 (ICAM-1), E-selectin and vascular cell adhesion molecule-1 (VCAM-1) in human malignancies. Br f Cancer 1993; 68: 122-4.

21 Tsujisaki M, Imai K, Hirata $H$, Hanzawa $Y$, Masuya J, Nakano $\mathrm{T}$, et al. Detection of circulating intercellula molecule-1 antigen in malignant diseases. Clin Exp Immunol 1991; 85: 3-8.

22 Most J, Zangerle R, Herold $M$, Fuchs D, Wachter $H$, Fritsch $\mathrm{P}$, et al. Elevated concentrations of circulatin intercellular adhesion molecule 1 (ICAM-1) in HIV-1 infection. F Acquir Immune Defic Syndr 1993; 6: 221-6.

23 Schopf RE, Naumann S, Rehder M, Morsches B. Soluble intercellular adhesion molecule-1 levels in patients with psoriasis. Br $₹$ Dermatol 1993; 128: 34-7.

24 Acrocker-Mettinger E, Steurer-Georgiew L, Steurer M, Huber-Spitzy, Hoelzel E, Grabner G, et al. Circulating ICAM-1 levels in serum of uveitis patients. Curr Eye Res 1992; 11: S161-6.

25 Leeuwenberg JFM, Smeets EF, Neefjes J, Schaffer MA Cinek T, Jeunhomme JFM, et al. E-Selectin and intercellular adhesion molecule- 1 are released by activated human endothelial cells in vitro. Immunology 1992; 77: 543-9.

26 Meyer D, Baumgartner HR. Role of von Willebrand factor in platelet adhesion to the subendothelium. Brf Haematol 1983; 54: 1-9.

27 Giustolisi R, Musso R, Cacciola E, Cacciola RR, Russo M, Petralito A. Abnormal plasma levels of factor VIII/Von Willebrand factor complex in myocardial infarction expression of acute phase reaction or index of vascular expression of acute phase reaction or index of vascular

28 Best WR, Becktel JM, Singleton JW, Kern F. Development of a Crohn's Disease Activity Index. National co-operative Crohn's disease study. Gastroenterology 1976; 70: 439-44.

29 Truelove SC, Witts LJ. Cortisone in ulcerative colitis. Final report on a therapeutic trial. $B M \mathcal{F} 1955 ; 2$ : $1041-8$.

30 Pigott R, Dillon LP, Hemingway IK, Gearing AJH. Soluble forms of E-selectin, ICAM-1 and VCAM-1 are present in the supernatants of cytokine-activated endothelial cells. Biochem Biophys Res Commun 1992; 187: 584-9.

31 Short PE, Williams CE, Picken AM, Hill FGF. Factor VIII related antigen: an improve

Lab Sci 1982; 39: 351-5. Malizia G, Calabrese A, Cottone Trejdosiewicz LK, Smart CJ, et al cyte adhesion molecules by mucosal mononuclear phagocytes in inflammatory bowel disease. Gastroenterology 1991; 100: 150-9.

33 Yamaguchi $T$, Morise $\mathrm{K}$, Kimura M, Horiuchi $\mathrm{Y}$. Immunohistochemical analysis of colonic mucosa with ulcerative colitis-activation of lymphocytes and expression 
of ICAM-1 by lamina propia dendritic cells and macrophages (Japanese). Nippon Scokakibyo Gakkai Zasshi 1992; 89: 17-27.

34 Nakamura $S$, Ohtani $H$, Watanabe $Y$, Fukushima $K$ Matsumoto T, Kitano A, et al. In situ expression of the cell adhesion molecules in inflammatory bowel disease. cell adhesion molecules in

35 Koizumi M, King N, Lobb R, Benjamin C, Podolsky DK Expression of vascular adhesion molecules in inflammatory bowel disease. Gastroenterology 1992; 103: 840-7

36 Ohtani H, Nakamura S, Watanabe Y, Fukushima K, Mizoi $\mathrm{T}$, Kimura $\mathbf{M}$, et al. Light and electron microscopic immunolocalization of endothelial leucocyte adhesion molecule-1 in inflammatory bowel disease. Virchows Archiv A Pathol Anat Histopathol 1992; 420: 403-9.

37 Springer TA. The sensation and regulation of interactions with the extracellular environment: the cell biology of lymphocyte adhesion receptors. Ann Rev Cell Biol 1990; 6: 359-402.

38 Kelly CP, O'Keane JC, Orellana J, Schroy III PC, Yang C, Lamont $\mathrm{T}$, et al. Human colon cancer cells express Lamont $T$, et al. Human colon cancer cells express ICAM-1 in vivo and support LFA-1 dependent lympho-

39 Pober JS, Cotran RS. Cytokines and endothelial cell biology. Physiol Rev 1990; 70: 427-51.

40 Osborn L. Leukocyte adhesion to endothelium in inflammation. Cell 1990; 62: 3-6.

41 Jones SC, Haidar A, Hagan P, Crabtree JE, Banks RE, Axon ATR, et al. Cytokine production in the mucosa of patients with inflammatory bowel disease. Eur $\mathscr{f}$ Gastroenterol Hepatol 1993; 5: 607-12.
42 Macdonald TT, Hutchings $P$, Choy MY, Murch S, Cooke A. Tumour necrosis factor-alpha and interferon-gamma production measured at single cell level in normal and inflamed human intestine. Clin Exp Immunol 1990; 81: 301-5.

43 Mahida YR, Lamming CED, Gallagher A, Hawthorne AB Hawkey CJ. 5 Aminosalicylic acid is a potent inhibitor of IL-1 beta production in organ culture of colonic biopsy specimens from patients with inflammatory bowel disease. Gut 1991; 32: 50-54.

44 Adams DH, Hubscher SG, Shaw J, Rothlein R, Neuberger $\mathrm{JM}$. Intercellular adhesion molecule 1 on liver allografts during rejection. Lancet 1989; ii: 1122-5.

45 Pottinger BE, Read RC, Paleolog EM, Pearson JD. Von Willebrand factor is an acute phase reactant in man. Thromb Res 1989; 53: 389.

46 Stevens TRJ, James JP, Simmonds NJ, McCarthy DA, Laurenson IF, Maddison PJ, et al. Circulating von Willebrand factor in inflammatory bowel disease. Gut 1992; 33: 502-6.

47 Wakefield AI, Sawyert AM, Dhillon AP, Pittilo RM, Rowles PM, Lewis AA, et al. Pathogenesis of Crohn's disease: multifocal

48 Baumann $\mathrm{H}$, Gauldie J. The acute phase response. Immunol Today 1994; 15: 74-80.

49 Wellicome SM, Kapahi P, Mason JC, Lebranchu Y, Yarwood $\mathbf{H}$, Haskard DO. Detection of a circulating form of vascular cell adhesion molecule-1: paired levels in rheumatoid arthritis and systemic lupus erythematosus. Clin Exp Immunol 1993; 92: 412-8. 